Annals of Warsaw University of Life Sciences - SGGW

Land Reclamation No 49 (2), 2017: 81-94

(Ann. Warsaw Univ. of Life Sci. - SGGW, Land Reclam. 49 (2), 2017)

\title{
The integrated assessment of natural resources status at the rural commune - case study of the Olszanka, Mazovian Voivodeship
}

\author{
JUSTYNA MAJEWSKA, BOGUMIŁA PAWLUŚKIEWICZ, KAZIMIERZ PIEKUT
}

Faculty of Civil and Environmental Engineering, Warsaw University of Life Sciences - SGGW

\begin{abstract}
The integrated assessment of natural resources status at the rural commune - case study of the Olszanka, Mazovian Voivodeship. The assessment of the possibilities of the integrated index method application for the determination of the environmental resources values to mark out the developing trends for the rural commune was the aim of the work. The typical agricultural commune Olszanka, located in Mazovian Voivodeship, was chosen for the case study. The land use structure, the quality of agricultural production area, water, soil, air, biological diversity and landscape were being analyzed as the components of the natural agricultural environment. The high spatial differentiation of analyzed components of the rural environment was proved. The applied method may be used for working out the development strategy for another rural communes, because it takes into consideration the status of area resources in qualitive, quantative and spatial forms and enables the assessment of the issue in systemic way with accuracy sufficient to the problem complexity.
\end{abstract}

Key words: the rural sustainable development, agricultural environment, environmental resources, rural commune, the index method

\section{INTRODUCTION}

The idea of sustainable development of rural areas relates to the maintaining the agricultural activities with simultaneous preservation of natural environment (Rokicki 2010). Its introduction arises from the growing awareness of agriculture and natural environment interaction, the depletion of natural resources and the deterioration of environment components. In the conditions of intensive agricultural production the reduction of negative effect of agriculture is a one of the tasks of the EU Commune Agricultural Policy. Despite the introduction of the mechanism and financial encourages for using the agricultural lands in accordance with the requirements of natural environmental protection (Regulation (EU) $1306 / 2013,1307 / 2013,1310 / 2013)$, the dissemination of sustainable development has got only theoretical character. The development strategies for the area are being formulated on the levels of voivodeships or districts and frequently they do not fit to real, local environmental and socioeconomic condition of the communes (Kistowski et al. 2009). Unsatisfactory level of sustainable development is being noticed not only in poor recognition of environmental resources, but also in the lack of indictors allowing the determination of the actual balance - level in the commune area, the monitoring of its changes and the assessment of the undertaking actions affectivity.

The aim of the work is the application of the integrated index method for the environmental resources evaluation in chosen rural commune. The worked out method should make easier the deter- 
mination of the directions of rural areas development, based mainly on internal domestic environmental resources.

\section{MATERIAL AND METHODS}

The Olszanka commune of typical agricultural character, located in eastern part of Poland was the studied area. The assessment of the natural resources was carried out accordingly with authors' index method for the determination of the environment resources' value (Majewska 2015, 2016), which assumes four methodical steps. First step covers the analyze of internal and external conditions of the rural area development at different levels of accuracy. The second step comprises the analyze of the indicators of rural area sustainable development, covering the selection of the indicators, their aggregation and normalization. The 26 various partial indicators and 17 detailed indicators were taken into account. The normalization was performed for specific indicators, which relied on the reducing their values to the commune five-grade scale. The third step relied on the determination of the areas' value and their balance level. In that step the following activities were being performed: the assessment of the status of particular environmental components on the base of calculated partial indicators $(W c)$ and particular $(W s)$; the assessment of the general level of the area environmental equilibrium $(V)$ with formula $V=\sum W g i \cdot r i$ where: $W g i$ - the value of and environment's component [ $1-5$ points]; $r i-$ importance and value of environment components; importance sum equals to 1 , where five levels of sustainability were distinguished (strongly unsustainable -1 point; strongly sustainable -5 points). Additionally, the assessment of spatial balance was distinguish, which requires the individual analyses for particular communes. It consists in the assessment of the state of identified internal resources on the base of initial data and the results of the field studies as well the data in larger scales obtained due the cartographic presentation and assuring the required spatial separation and the data accuracy. Fourth step contains the analyze of possible rural area development' directions, taking into consideration new functions and operations for shaping the environment of rural area.

The identification and assessment of the state of particular resources of the natural and agricultural environment in the commune were determined on the base data from Bank Danych Lokalnych (BDL), supplemented with the ones from detailed, cameral and field studies carried out in the years 2008-2012, accordingly with generally accepted methods for investigated issue (Table 1). The field studies regarding the determination of the botanical composition, yields and the swards of grasslands were carried out in Toczna river valley on three representative cross-sections (upper, midland and lower section of the river valley). The distribution and the status of the environmental resources were determined with taking into account the level of the commune and the village, in dependence to the available data and the accuracy of the studies. The data analysis and working out with use of ArcGIS program were performed in the following scales: $1: 5000 ; 1: 10000$ and $1: 25000$. For delineation of homogeneous areas, able 
TABLE 1. The investigated elements, the data sources and the methods of investigation of natural and agricultural environment resources status of Olszanka commune area

\begin{tabular}{|c|c|c|}
\hline Investigated element & Data source & Method \\
\hline \multicolumn{3}{|c|}{ Natural resources } \\
\hline Water quality & $\begin{array}{l}\text { Field investigations } \\
\text { (6 times, } 6 \text { sampling points, } \\
\text { Toczna river })\end{array}$ & $\begin{array}{l}\text { Acidity }(\mathrm{pH}) \text { and electrolytic conductivities of } \\
\text { water - gauge WTW MultiLine P4 } \\
\text { (pH - electrode WTW SenTix81, conduciveness } \\
\text { - electrode TetraCon325). Content } \\
\text { of phosphorus, nitrogen and potassium - spectro- } \\
\text { photometer }\end{array}$ \\
\hline $\begin{array}{l}\text { Natural-landscape } \\
\text { valour's }\end{array}$ & \begin{tabular}{|l} 
Field investigations \\
(Toczna river valley) 2009
\end{tabular} & $\begin{array}{l}\text { Simplified method of index evaluation (Oglęcki } \\
\text { and Pawłat 2000) }\end{array}$ \\
\hline $\begin{array}{l}\text { Grasslands botanical } \\
\text { composition }\end{array}$ & $\begin{array}{l}\text { Field investigations } \\
\text { (42 samples) } 2009\end{array}$ & $\begin{array}{l}\text { Weight-botanical analyze (Stebler and Schröter } \\
\text { 1892) first cut }\end{array}$ \\
\hline $\begin{array}{l}\text { Grasslands plant } \\
\text { communities }\end{array}$ & \begin{tabular}{|l|} 
Field investigations \\
$(50$ phytosociological \\
surveys, may 2011)
\end{tabular} & Phytosociological surveys (Braun-Blanquet 1964) \\
\hline \multicolumn{3}{|c|}{ Agricultural resources (production conditions) } \\
\hline $\begin{array}{l}\text { Structure of land and } \\
\text { agricultural land use }\end{array}$ & $\begin{array}{l}\text { Topographic maps } 1: 10000 ; \\
\text { Commune Olszanka land us- } \\
\text { age and productiveness maps } \\
1: 10000 ; \text { agricultural-soil } \\
\text { maps } 1: 25000 \text { and ortopho- } \\
\text { tomaps }\end{array}$ & Cartographic analysis, ArcGIS \\
\hline $\begin{array}{l}\text { Value of agricultural } \\
\text { productive space }\end{array}$ & Agricultural-soil maps IUNG & $\begin{array}{l}\text { Synthetic indicator of agricultural space value } \\
\text { (Witek 1977) included soil points' quality, type of } \\
\text { terrain relief, water conditions and agroclimate }\end{array}$ \\
\hline Grassland yields & $\begin{array}{l}\text { Field investigations } \\
\text { 2008-2009 (60 samples) }\end{array}$ & $\begin{array}{l}\text { Plate's method (Kostuch 1981) 2008, first cut } \\
12 \text { replications; } \\
\text { Method of trial's cuts } 2009 \text { from } 1 \mathrm{~m}^{2} \text {. } \\
\text { First harvest } 39 \text { cuts } \\
\text { (I cross-section 12; II-13, III-14 cuts); second } \\
\text { harvest adequately } 4,8,6 \text { cuts in cross-sections }\end{array}$ \\
\hline $\begin{array}{l}\text { Fodder value of } \\
\text { meadow sward }\end{array}$ & $\begin{array}{l}\text { Field investigations } 2009 \\
\text { (42 samples) }\end{array}$ & Botanical method (Filipek 1973), first cut, May \\
\hline Soil erosion & Topographic maps & $\begin{array}{l}\text { Cartographic analysis, five-grade scale (Prochal } \\
\text { 1987) }\end{array}$ \\
\hline
\end{tabular}

to perform the particular functions, the topographic maps $1: 5000$ and ortophotomap sheets, vector's data soil-agriculture from IUNG and ArcGIS program were used. For the identification of the area functions the chosen indicators of rural development in local scale and the commune resources were used. For the distinguishing of the villages groups of similar features of the studied parameters the method of hierarchic aggregation was being used. The following features were analyzed: the value of the synthetic indicator of agricultural' produc- 
tion space, the share of protected areas, particular indicators regarding land use (grasslands, forests, unused and wooded area, water reservoirs and wetlands).

\section{RESULTS}

\section{First step}

\section{Urbanization, physiographical and environmental determinants}

The Olszanka commune is located in eastern part of Mazovian Voivodeship in Łosice County and covers the area of 8,762 ha. The terrain relief is little various. The commune area lies in the Bug river catchment basin and constitutes the terrains of Toczna, Liwiec and Krzna Północna sources. The Toczna river is a left tributary of the Bug river and flows out from water reservoir Stójło, located in the Korczówka village.

The Olszanka commune consists of 17 villages. Population density is 85 inhibitants per $1 \mathrm{~km}^{2}$. The agriculture is the basic source of income for commune inhabitants, 188 registered firms operate here, including 41 representing first sector (agriculture, forestry, hunting and fishing).

The road density is about $126 \mathrm{~km}$ per $100 \mathrm{~km}^{2}$. The commune has not access to gas pipes and is lack of the wastewater purification plant. The total length of water supply network in commune's area is $91.4 \mathrm{~km}$ according to Bank Danych Lokalnych data from 2010.

On the terrain of the commune the Toczna river flows on the cross-section of about $9 \mathrm{~km}$, from the spring to $\mathrm{km}$ $31+800$. The magnitude of river catchment in commune amounts $12.3 \%$ of its total catchment area. The Toczna river is being classified as strongly changed homogenous part of water. Its ecological potential was determined as poor (Zestawienie... 2012). The authors' studies of the chosen parameters of physical and chemical parameters (NPK, transparente, $\mathrm{pH}$ ) proved the good water status in the river and Stójło reservoir, with regard to obligatory norms (Dz.U. 2011 r. nr 257, poz. 1545).

On the commune area the soils of III-VI quality classes occure. The best soils of class III cover $11 \%$ of the surface of arable lands and $7.5 \%$ of the grasslands. The largest fragment of those soils is located on the area of the villages Bejdy, Bolesty, Mszanna, Olszanka, Pietrusy, Próchenki, Szawły and Wyczółki (Fig.). The soils of class IV stand $58 \%$ area of arable lands and $46.6 \%$ area of the grasslands. The soils of class $\mathrm{V}$ stand $28 \%$ surface of arable lands and $44.3 \%$ of grasslands area, and class VI $-3 \%$ area of arable lands and $1.6 \%$ of grasslands (Program ochrony... 2005).

On the area of the commune the parts of local and regional natural range, inluding water reservoirs, low peatland and valley's meadows. Seven per cent of the commune is covered by Nature 2000 Dolina Liwca PLB 140002 area. The most precious sites are preserved by local Law since 2002 (Uchwała... 2002). The surveys of grassland communities, carried out in Toczna river valley, showed the occurrence of four orders of plants assemblies: Magnocaricion, Arrhenatheretalia elatioris, Molinietalia caeruleae and Agropyro-Rumicion crispi. The largest share $(54.3 \%)$ was characterized for Arrhenatheretalia elatioris. In the central part of the valley, on humid meadows, 
the occurrence of protected plant species Dactylorhiza incarnata was stated.

The ecological model of external conditions was determined as partially isolated one. The internal ecological structure of the commune landscape was assessed as composed by many-axes (two-axes), striped, mid-abundant (Żarska 2006). The highest natural landscape values of the Toczna river valley were stated at the medial cross-section of the valley. They represented $12.1 \%$ of the evaluated area and were bound basically with the meanders of the river bank and the occurrence of coppices. On $45 \%$ of the surface area natural landscape values were assessed as average, but very low - on $24 \%$ of the area. The low valorousness was effected basically by the flow speed and water color.

\section{Assesment of agricultural and natural resources}

Agricultural lands cover over $80 \%$ of the commune area, including almost $65 \%$ of arable lands and $12 \%$ of the permanent grasslands. The highest share of agricultural land is typical for the Kolonia Korczówka village (91.98\%). The highest share of permanent grasslands was typical for the Klimy village (26.97\%). The highest shares of the afforested areas were stated for the Bejdy (22.93\%) and Hadynów (22.74\%) villages. The largest share of urbanized areas of was stated for the Szydłówka village (3.54\%).

The soils suitable for cultivation plants of low demands for the fertility and water conditions dominate in the commune. The highest share on arable land was stated for the complex 5 - rye good $(28.0 \%)$, followed by complex 6 - rye poor $(23.4 \%)$ and rye very good
$(22.5 \%)$. On the grasslands the highest share was stated for the complex $2 z-$ medium grasslands (14.2\%). The advantage conditions for agricultural production were stated only for the Wyczółki village. The average conditions were found in the villages Bolesty, Kolonia Korczówka and Szawły. The synthetic indicator of agricultural space value for productivity for all the commune was equal to 58.9 points. The cultivations of cereals dominated, basically the rye $(23.1 \%)$, the triticale $(17.9 \%)$ and the oats $(17.8 \%)$. The potatoes cultivations covered almost $11 \%$ of the arable ground surface. The application of nitrogen fertilizers in the commune amounted $54.5 \mathrm{~kg} \cdot \mathrm{ha}^{-1} \mathrm{UAA}$, but the application of mineral NPK was equal to only $93.7 \mathrm{~kg} \cdot \mathrm{ha}^{-1}$ UAA. The largest share of agricultural lands was owned by individual farmers (over $90 \%$ ). of the highest share of the arable lands was in good agricultural conditions (99\%) (GUS 2010). The market agriculture production in the commune was equal to $80 \%$. The cattle and pigs dominated in animal production.

\section{Second step}

Methodical element for the third step obtaining, of intermediary character and does not scope the results of the case study.

\section{Third step}

Assesment of environmental components value

The values of partial indicators describing the state of equilibrium amounted from 1 point to 3.5 points in five-point scale. The lowest value characterized the indicators of the canalization infrastructure's state (1 point). The indicator of 


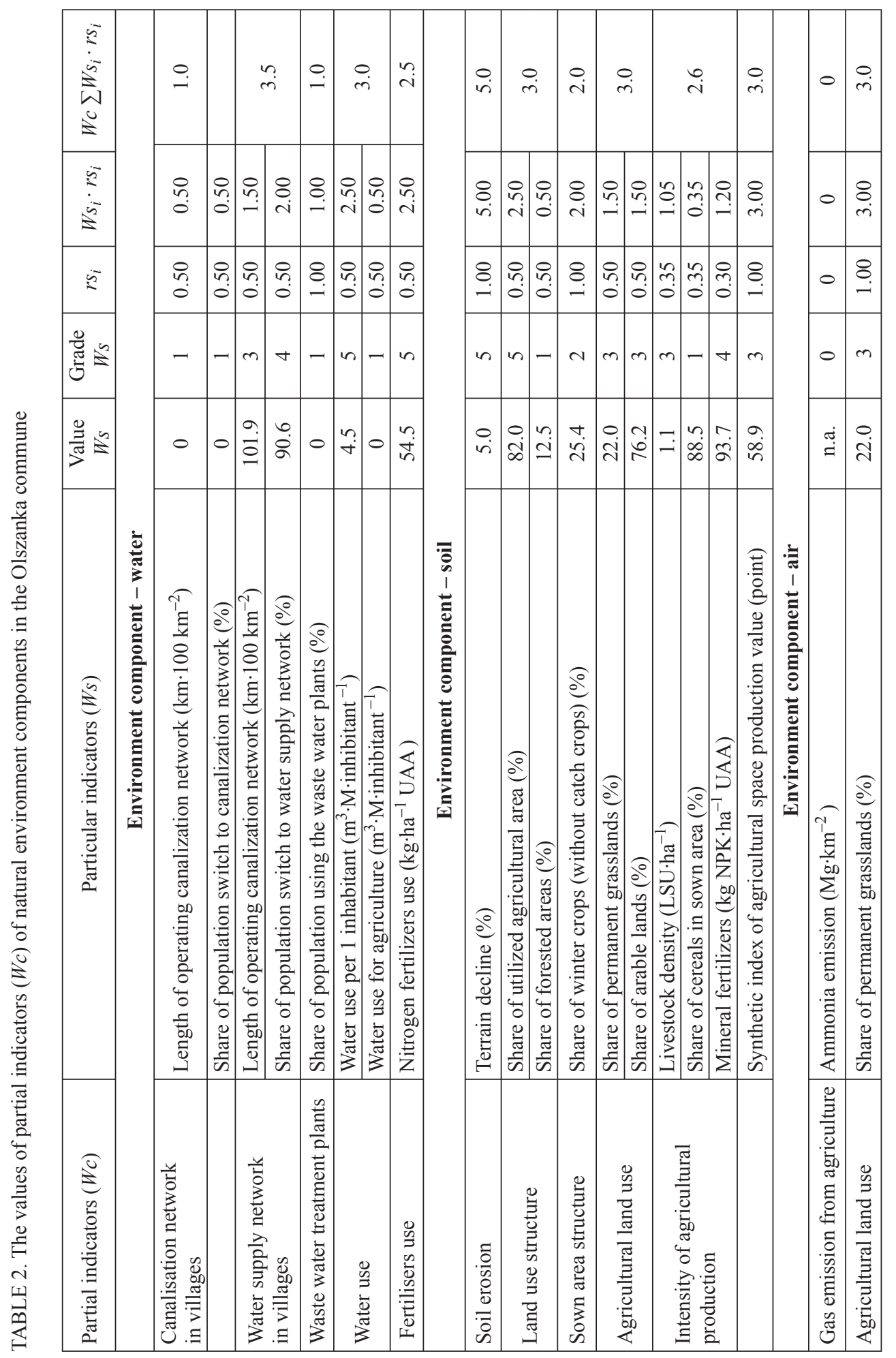




\begin{tabular}{|c|c|c|c|c|c|c|c|c|c|c|c|c|c|c|c|c|c|c|}
\hline 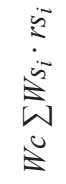 & & $\stackrel{\circ}{-}$ & $\stackrel{0}{\dot{n}}$ & $\stackrel{0}{-}$ & & $\stackrel{0}{\dot{r}}$ & $\stackrel{\circ}{+}$ & 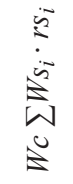 & & \multicolumn{4}{|c|}{$\stackrel{0}{i}$} & $\stackrel{\circ}{i}$ & \multirow{2}{*}{$\begin{array}{c}\stackrel{0}{r} \\
\\
\dot{8} \\
\dot{m}\end{array}$} & \multirow{2}{*}{$\begin{array}{l}0 \\
0 \\
0\end{array}$} & \multirow{2}{*}{\begin{tabular}{|l}
0 \\
- \\
\\
\end{tabular}} & \multirow{2}{*}{ 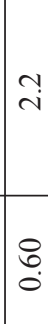 } \\
\hline$\hat{\tilde{2}}$ & & ח̊n & $\underset{r}{\stackrel{8}{r}}$ & $\underset{8}{8}$ & & $\underset{\dot{r}}{8}$ & $\begin{array}{l}8 \\
\dot{+}\end{array}$ & $\begin{array}{l}\dot{2} \\
\dot{s} \\
\dot{s}\end{array}$ & & $\stackrel{2}{\mathfrak{n}}$ & $\begin{array}{lll}2 & 4 \\
0 & 2 & \\
0 & 2\end{array}$ & 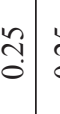 & ֶ̃ & \begin{tabular}{l|l} 
\\
\\
\end{tabular} & & & & \\
\hline$\overline{2}$ & & $\stackrel{\circ}{n}$ & $\underset{-}{8}$ & $\underset{8}{8}$ & & $\stackrel{8}{-}$ & $\stackrel{8}{8}$ & 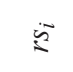 & & ñ & ra & $\stackrel{n}{n}$ & ก̃? & \begin{tabular}{l|l}
0 & 0 \\
\hdashline & $n$ \\
0
\end{tabular} & $\stackrel{8}{\stackrel{8}{ }}$ & 0 & $\stackrel{8}{8}$ & ก̊. \\
\hline 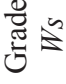 & & - & $m$ & -1 & & $m$ & $\nabla$ & $\overbrace{0}^{\pi}$ & & $n$ & $-1-$ & -7 & - & $m-$ & $m$ & 0 & - & $\sim$ \\
\hline 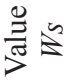 & & 0 & $\exists$ & 0 & & $\begin{array}{l}\infty \\
\infty \\
\infty\end{array}$ & $\hat{\sigma}$ & 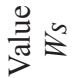 & & $\begin{array}{c}0 \\
i \\
\infty\end{array}$ & $\begin{array}{ll}\vec{\Delta} \\
\vec{i}\end{array}$ & $\stackrel{+}{\circ}$ & $\stackrel{n}{\simeq}$ & 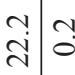 & $\begin{array}{l}\infty \\
\infty \\
\infty\end{array}$ & $\stackrel{\overbrace ্}{=}$ & ֻั & $\exists$ \\
\hline 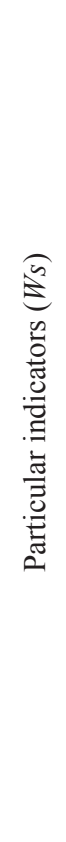 & 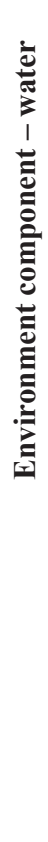 & 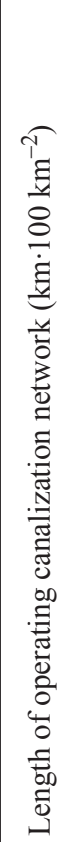 & 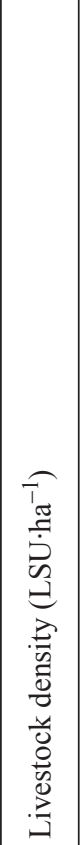 & 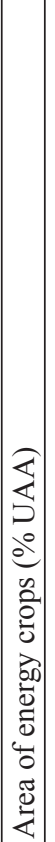 & 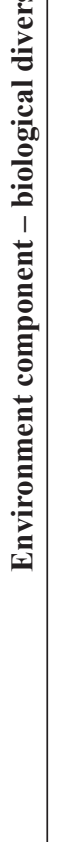 & 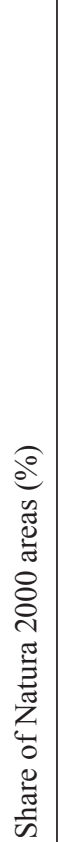 & 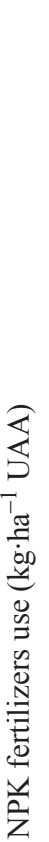 & 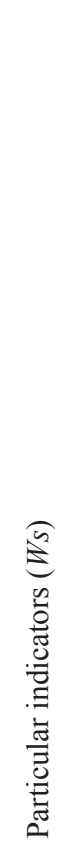 & 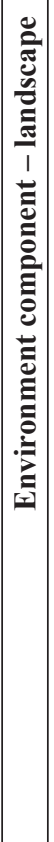 & 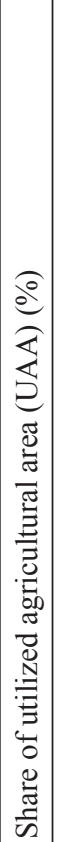 & 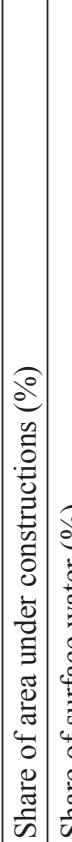 & 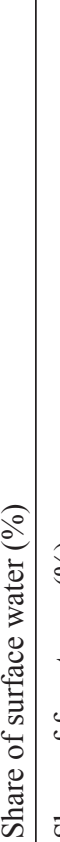 & 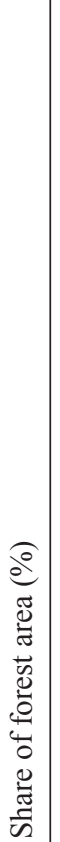 & 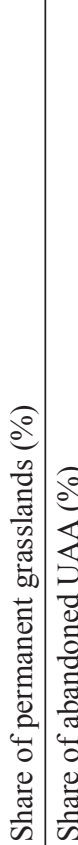 & 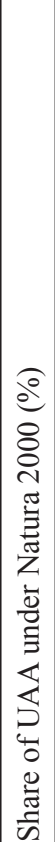 & 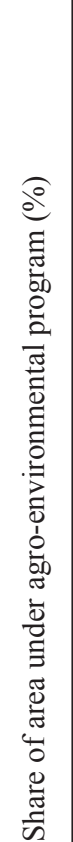 & 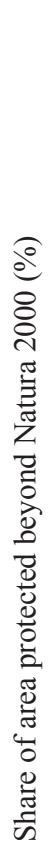 & 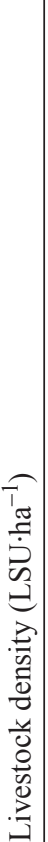 \\
\hline 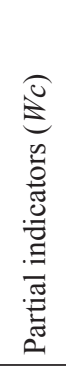 & & 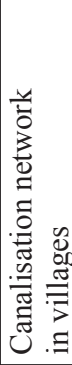 & 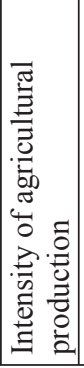 & 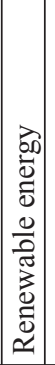 & & 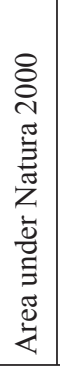 & 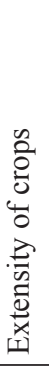 & 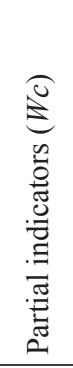 & & & 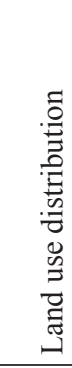 & & & 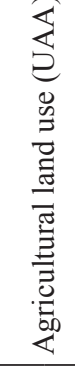 & 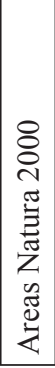 & 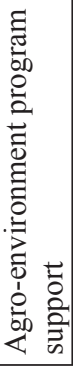 & 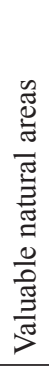 & 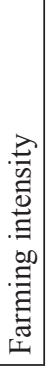 \\
\hline
\end{tabular}




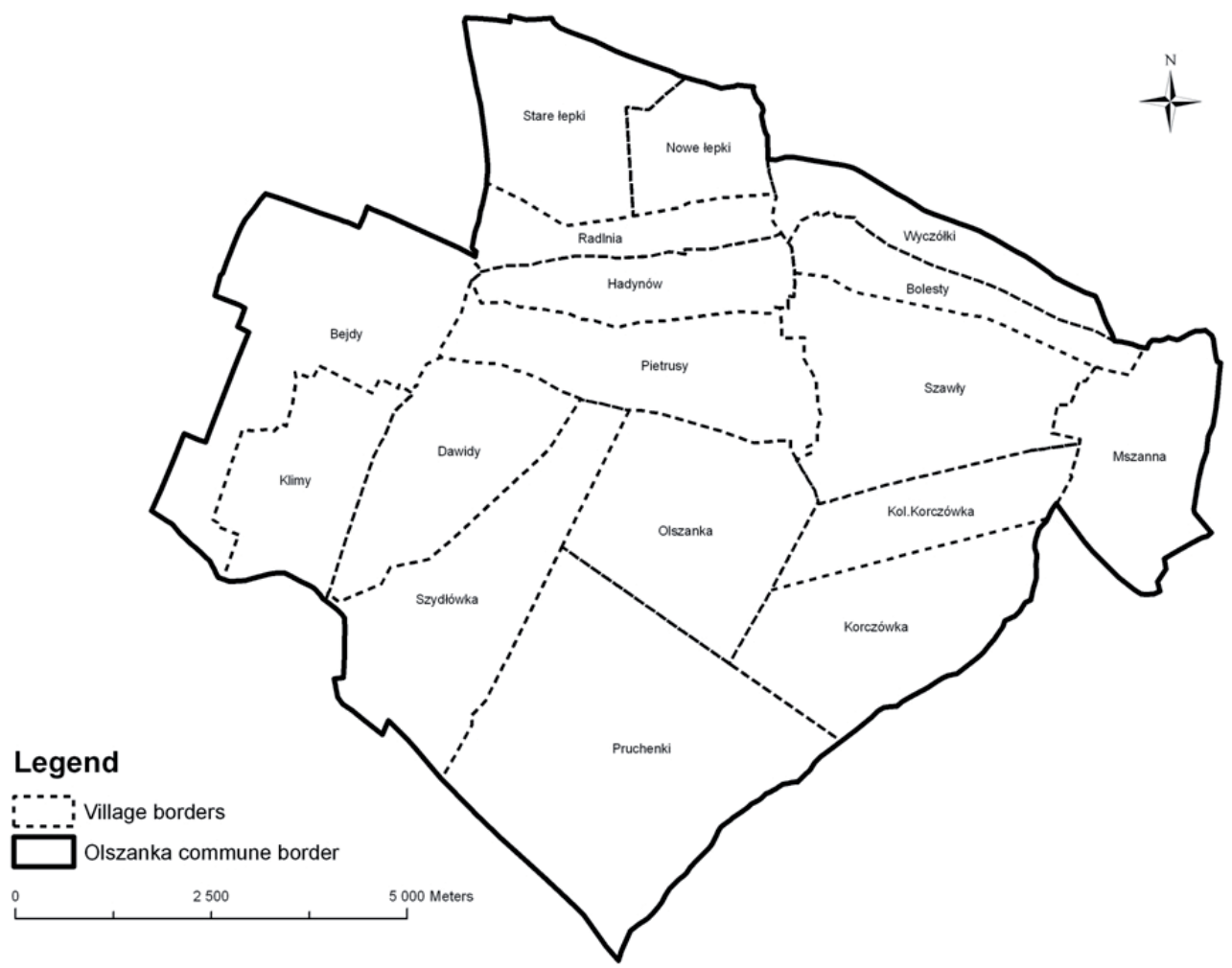

FIGURE. Localization of villages in the Olszanka commune

water network gained the highest grade (3.5 points), since relative high value of indicator - percentage of the population benefits from water supply network.

The partial indicators effecting the state of sustainability of that component amounted from 2 to 5 points. The indicator of highest value was the one describing soil erosion (5 points). The issues connected with the structure of sown area (low share of winter crops) seem to be disadvantageous in the terms of sustainable development. The rest of the indicators was assessed as average.

Air quality was determined by three partial indicators because the value of direct indicator - gas emission to atmos- phere - was not achieved. The values of the remaining indicators amounted from 1 point to 3 points, which points out the weak sustainability of that component. The lowest grade was achieved by therenewable energy indicator, since on the commune' area the energetic crops were not stated. The intensity of agricultural production and the structure of agricultural lands got 3 points, what means that their states were satisfactory.

Biological diversity was determined by two indicators. The index for crop extensity was high (4 points), what resulted from low use of NPK fertilizers per hectare. The Natura 2000 area indicator was equal to 3 points. 
The values of partial indicators for that component varied from 1 point to 3 points. The worst, in respect to sustainable development, was the indicator describing the size of natural-valuable area out of the Natura 2000 network. The highest value characterized the indicator linked to the share of the area in Natura 2000 network. The low values of the indicators determining the land use distribution and the production intensity ( 2 points) point out the necessity of the land use improvement.

The state of sustainability for all environment components in Olszanka commune varied from 2.1 to 3.5 points. The component of the highest was the biological diversity, basically because of the large share of Natura 2000 areas and extensive ways of plant cultivation in the commune. The remaining components showed the values below 3 points, what means that their state was unsatisfactory.

\section{Forth step}

\section{Assesment of environmental sustainability of the area}

The general level of environmental sustainability of Olszanka commune area was equal to 2.5 points. It means that the area is unsustainable and demands undertaking the actions supporting its development. The advantageous aspect connected with the studied area is biological diversity. This component should be the base of working out the development strategy for the Olszanka commune. The basic weakness of the area is the status of landscape component. Since undertaking the actions improving its status is necessary.
The spatial sustainability of the study area is presented by the compare analysis of the terrain declines, grasslands plant communities, the values of natural landscape in the Toczna river valley identified during field investigation and spatial differentiation of agricultural production' conditions.

The grade of the "terrain declines" indicator on the commune level showed the lack of the threats of surface erosion for environmental sustainability of the area development. It was proved that highest terrain declines are in the Toczna river valley and basin, what may be hazardous for the water quality in the watercourse. The lowest terrain declines were stated in the eastern and western parts of the commune area.

The analyze of spatial distribution of meadows' plant communities showed their significantly high differentiation in the valley. The most precious from environmental point of view are Molinietalia caeruleae communities - the humid meadows - were present in the central part of the valley on both its sides. They are very important for the environment, protecting water against surface pollutants, storing melting and flood-waters and protecting the soil against erosion and structural changes. Rich and valuable species composition of plant communities in the central part of the valley and inventoried site of the protected species allows for the statement that these valley parts are especially important in the aspect of biological diversity.

Natural landscape values of the Toczna river valley were highly various, from very low to very high. The longest homogenous cross-section $(2 \mathrm{~km})$ of valley is placed in its upper part. It characterizes 
itself by medium natural and landscape values. The highest values were estimated in the middle cross-section of the valley, because of meandering riverbed and the presence of numerous trees. The low values were presented for the cross-sections in the following villages: Hadynów, Bolesty, Szawły and Nowe Łepki. Very low ecomorphological value was figured out for the spring cross-section.

The value of agricultural production space index (58.9 points) shown the average level of the soil productivity in the commune. The agricultural grounds in the Wyczółki village were convenient for plant production, but the soils of Hadynów and Klimy - not. The largest part of the commune area characterized itself by low convinces to agricultural activity. The most productive and of highest nutritional value of the swards were the grasslands in lower part of the Toczna river valley. They were in average 5.45 higher than in middle cross-section and $24.2 \%$ higher than in upper cross-section. The utility value numbers ( $\mathrm{Lwu}$ ) were equal respectively 6.1 (good), 5.5 and 4.4 (poor).

\section{The strong and weak sides of Olszanka commune area}

The diagnosis of strong and weak sides of commune area was determined on the base of the internal environmental resources. The strong sides were linked to the biological diversity, connection of valley grasslands with terrain relief, low surface erosion threats and low water use per one inhabitant. The weak sides concern the lack of canalization infrastructure and inconvenient land use distribution (small area of forests and surface waters), and also the simplification of the crop rotation.

\section{The new functions of the Olszanka commune area}

The differentiation of the status and placement of natural and agricultural resources, as well as the analyze of strong and weak sides of the area, show that determination of the direction of the Olszanka commune development should take into account the local resources as the base for working out the functions of particular villages - productive, ecological and recreational ones.

The north-eastern part of the commune characterizes itself by the best conditions for fulfilling the productive functions. The activities on the rest of the grounds should go towards the new functions. The best conditions for ecological functions development were stated at the areas of the villages: Próchenki, Szydłówki, Klimy and Pietrusy; and to develop the recreational functions - the terrains of northern part of the commune.

The shaping the rural area environment of Olszanka commune

Proposed action aims towards the improvement of the status of these resources where the analysis pointed out the low level of their sustainability. The places of the realization of these actions, their kind and scope is presented in Table 3 .

Proposed actions have the character of eco-systems services, served by farmers for the entire UE society and may be financed from Structural Funds, especially EFRROW, and from Polish founds like NFOŚiGW or WFOŚSiGW. 


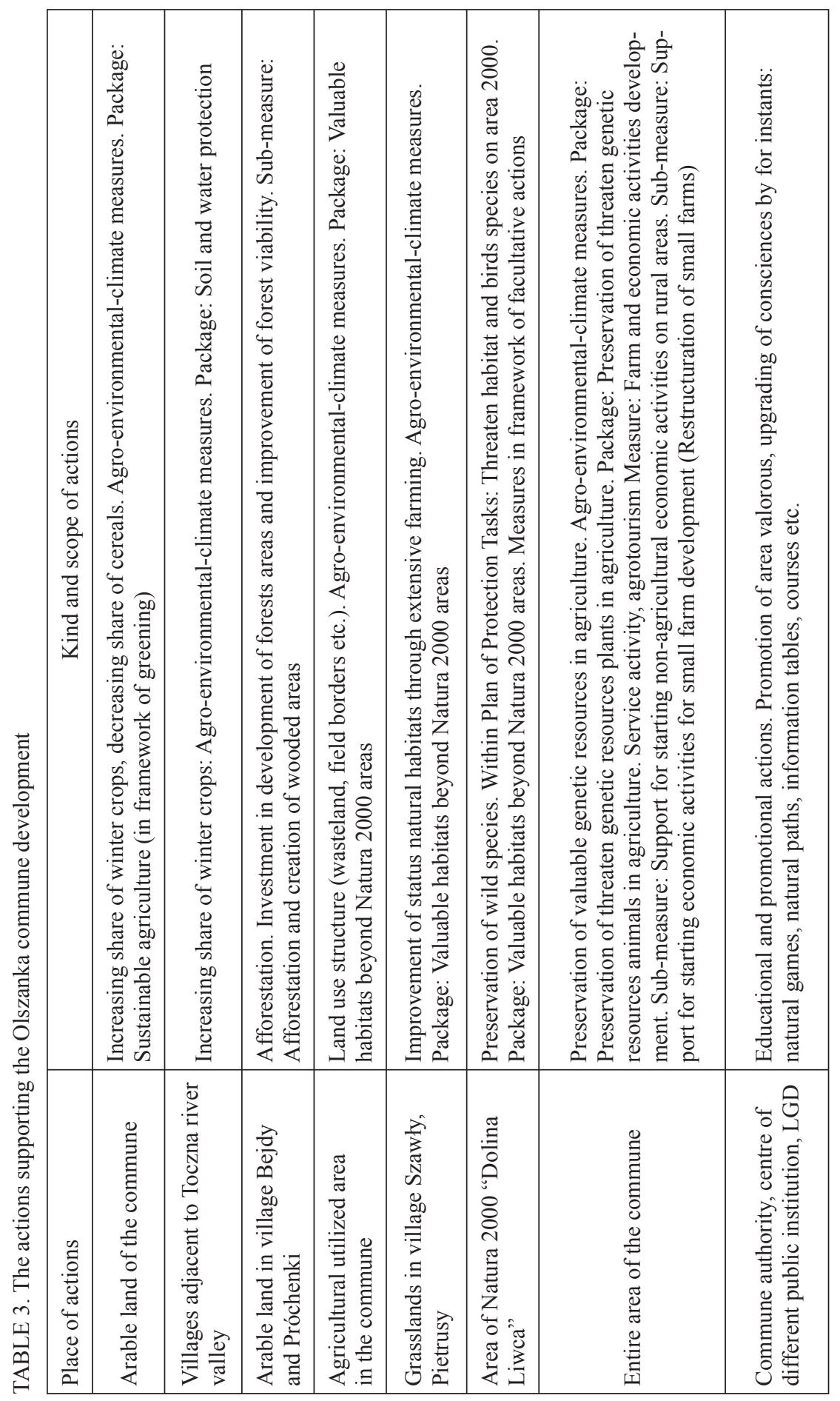




\section{CONCLUSIONS}

1. The detailed identification and valorization, taking into account the spatial differentiation of natural and agricultural resources and their presentation in cartography form in ArcGIS program, is necessary for working out the strategy of sustainable development of the rural area.

2. Environmental value of the area and the level of its general and spatial balance allows for the determination of strengths and weakness as well as the determination and localization of the actions in the range of protection and improvement of environment status, according to the determined direction of development of particular villages and monitoring the affectivity of their implementation.

3. The evaluation of the natural and agricultural environment of the O1szanka commune, conducted with the help of the integrated index method, shows that the general level of environmental sustainability is equal to 2.5 points. The strong side of the area is its biological diversity -3.5 points. The weak side, requiring fast undertaking of improving actions, are the elements deciding about the following components: water (2.2 points), air (2.2 points) and landscape (2.1 points).

4. The analyze of the Olszanka commune environmental value shows large spatial differentiation of the environment resources status. It points out the necessity of taking into account the environmental conditions of particular villages for the creative directions of the commune development.
5. The management of the Olszanka commune environment, within villages located mainly in the Toczna river valley - Próchenki, Klimy, Szydłówka and Pietrusy, should take into account the actions towards the preservation of biological diversity. The actions in the villages Szawły, Bejdy and Hadynów should take into consideration the improvement of green infrastructure for spreading the recreational function. The productive function of the commune area should be fulfilled by the villages Wyczółki, Bolesty, Kolonia Korczówka and Szawty with the intensity allowing the reproducibility of natural environment resources. Such types of actions are being covered by the Rural Development Plan 2014-2020.

6 . The developed method of integrated environmental evaluation may be used for the preparation of rural communes' strategies since it takes into account the status of the resources in qualitative, quantitative and spatial dimensions and in synthetic way allows the assessment carried out with the precision responding to the problem complexity.

\section{REFERENCES}

BRAUN-BLANQUET J. 1964: Pflanzensoziologie. Springer. Wien, New York.

GUS 2010: Powszechny spis rolny 2010. Retrieved from http://stat.gov.pl/spisy-powszechne/powszechny-spis-rolny-2010/ psr2010-wyniki-spisu-rolnego.

FILIPEK J. 1973: Projekt klasyfikacji roślin łąkowych i pastwiskowych na podstawie liczby wartości użytkowej. Post. Nauk Rol. PAN 4/141, 59-68 [in Polish]. 
KISTOWSKI M., SZCZYPAŃSKA A., MICHAŁOWSKA K. 2009: Wskaźniki skuteczności ochrony przyrody w dokumentach z zakresu polityki ekologicznej - potrzeby a rzeczywistość. Probl. Ocen Środ. 2 (45), 22-37 [in Polish].

KOSTUCH R. 1981: Praktyczne sposoby wyceny wydajności użytków zielonych metodą szacunkowo-pomiarową. Wyd. Wojewódzkiego Ośrodka Postępu Rolniczego. Korytniki [in Polish].

MAJEWSKA J. 2015: Indeksowa metoda oceny zasobów przyrodniczych obszarów wiejskich. PN IKS 70, 372-380 [in Polish].

MAJEWSKA J. 2016: Analiza możliwych kierunków rozwoju obszarów wiejskich - metoda indeksowa. PN IKS 25 (4), 497-506 [in Polish].

OGLECCKI P., PAWŁAT H. 2000: The index method of small lowland river environmental evaluation. Ann. Warsaw Agri. Uni. Land Reclam. 30, 37-43.

PROCHAL P. 1987: Podstawy melioracji rolnych. Vol. 2. PWRiL, Warszawa [in Polish].

Program ochrony środowiska dla gminy Olszanka na lata 2005-2012, 2005.

Regulation (EU) No 1306/2013 of the European Parliament and of the Council of 17 December 2013 on the financing, management and monitoring of the commune agricultural policy and repealing Council Regulations (EEC) No 352/78, (EC) No 165/94, (EC) No 2799/98, (EC) No $814 / 2000$, (EC) No $1290 / 2005$ and (EC) No 485/2008.

Regulation (EU) No 1307/2013 of the European Parliament and of the Council of 17 December 2013 establishing rules for direct payments to farmers under support schemes within the framework of the commune agricultural policy and repealing Council Regulation (EC) No 637/2008 and Council Regulation (EC) No 73/2009.

Regulation (EU) No 1310/2013 of the European Parliament and of the Council of
17 December 2013 laying down certain transitional provisions on support for rural development by the European Agricultural Fund for Rural Development (EAFRD), amending Regulation (EU) No 1305/2013 of the European Parliament and of the Council as regards resources and their distribution in respect of the year 2014 and amending Council Regulation (EC) No 73/2009 and Regulations (EU) No 1307/2013, (EU) No 1306/2013 and (EU) No 1308/2013 of the European Parliament and of the Council as regards their application in the year 2014.

ROKICKI T. 2010: Zrównoważony rozwój obszarów wiejskich przy wykorzystaniu produkcji owczarskiej. In: B. Kryk (Ed.). Rolnictwo w kontekście zrównoważonego rozwoju obszarów wiejskich. Economicus, Szczecin, 195-208 [in Polish].

Rozporządzenie Ministra Środowiska z dnia 9 listopada 2011 r. w sprawie sposobu klasyfikacji stanu jednolitych części wód powierzchniowych oraz środowiskowych norm jakości dla substancji priorytetowych (Dz.U. $2011 \mathrm{nr}$ 257, poz. 1545).

STEBLER F.C., SCHRÖTER C. 1892: Versuch eine übersicht über die Wiesentypen der Schweiz. Landw. Jahrb. d. Schweiz, 95-212.

Uchwała Nr XXXVII/190/02 w sprawie wprowadzenia użytków ekologicznych. Rada Gminy Olszanka, Olszanka 2002 [in Polish].

WITEK T., GÓRSKI T. 1977: Przyrodnicza bonitacja rolniczej przestrzeni produkcyjnej w Polsce. Wydawnictwa Geologiczne, Warszawa [in Polish].

Zestawienie tabelaryczne danych do klasyfikacji stanu ekologicznego i chemicznego rzek w JCW - ocena za 2012 r. 2013 [in Polish].

ŻARSKA B. 2006: Modele ekologiczno-przestrzenne i zasady kształtowania krajobrazu gmin wiejskich. Wydawnictwo SGGW, Warszawa [in Polish]. 
Streszczenie: Zintegrowana ocena stanu zasobów naturalnych gminy wiejskiej. Studium przypadku gminy Olszanka. Celem pracy jest ocena możliwości wykorzystania zintegrowanej indeksowej metody określania wartości zasobów środowiska do wyznaczenia kierunku rozwoju gminy wiejskiej. Metoda zakładała kroki metodyczne: określenie uwarunkowań rozwoju gminy; opracowanie wskaźników zrównoważonego rozwoju obszarów wiejskich na podstawie danych z Banku Danych Lokalnych (BDL) uzupełnionych badaniami własnymi; określenie stanu środowiska przyrodniczego obszaru i poziomu jego zrównoważenia oraz analizę możliwych kierunków rozwoju obszarów wiejskich obejmującą określenie nowych funkcji obszaru oraz działań kształtujących środowisko obszaru wiejskiego. Do studium przypadku wybrano położoną w województwie mazowieckim gminę typową rolniczą - Olszankę. Analizowanymi komponentami środowiska przyrodniczo-rolniczego były: struktura użytkowania ziemi, jakość rolniczej przestrzeni produkcyjnej, woda, gleba, powietrze, różnorodność biologiczna i krajobraz. Obliczony ogólny poziom środowiskowego zrównoważenia obszaru gminy Olszanka wynosił 2,5 pkt. Oznacza to, że potrzebne jest podjęcie działań wspomagających rozwój obszarów wiejskich w tym rejonie. Najmocniejszą stronę obszaru jest różnorodność biologiczna. Komponent ten powinien stanowić podstawę w opracowywanej strategii rozwoju gminy Olszanka. Najsłabszą stroną obszaru jest stan krajobrazu, który wymaga działań naprawczych. Zróżnicowanie stanu i przestrzennego rozmieszczenia zasobów przyrodniczych i rolniczych oraz analiza mocnych i słabych strony obszaru wskazuje, że przy opracowaniu kierunków rozwoju gminy Olszanka powinno uwzględnić się zasoby lokalne i na tej podstawie określać funkcje poszczególnych wsi: produkcyjną, ekologiczną i rekreacyjną. Najlepszymi warunkami do pełnienia funkcji produkcyjnej i rolniczej charakteryzuje się północno-wschodnia część gminy. Najdogodniejsze warunki do rozwoju funkcji ekologicznej mają tereny na południu gminy, a do rozwoju funkcji rekreacyjnej - północna część obszaru gminy. Wykazane duże zróżnicowanie przestrzenne zasobów środowiska przyrodniczego wskazuje na to, że przy tworzeniu kierunku rozwoju gminy należy uwzględniać uwarunkowania środowiskowe poszczególnych wsi. Zastosowana metoda może być wykorzystywana przy opracowywaniu strategii rozwoju innych gmin wiejskich, ponieważ uwzględnia stan zasobów obszaru w formach ilościowej, jakościowej oraz przestrzennej i z wystarczającą dokładnością umożliwia ocenę problemu w sposób syntetyczny.

\section{MS received June 2017}

\section{Authors' address:}

Justyna Majewska, Bogumiła Pawluskiewicz, Kazimierz Piekut

Katedra Kształtowania Środowiska

Wydział Budownictwa i Inżynierii Środowiska SGGW

ul. Nowoursynowska 159, 02-787 Warszawa

Poland

e-mail: justyna_majewska@sggw.pl 